\title{
R\&D activities of enterprises, product market leadership, and collusion ${ }^{* 1}$
}

\author{
Adam Karbowski², Jacek Prokop ${ }^{3}$
}

\begin{abstract}
The purpose of this study is to compare the consequences of, first, quantity leadership, and, second, price leadership competition of duopolists for their $R \& D$ investments, within the situation of a cartelized industry. Using game-theoretical approach and numerical analysis, it turns out that under quantity leadership, the $R \& D$ investments of enterprises decline with the increasing knowledge spillovers in the industry. The relative $R \& D$ expenditures of the Stackelberg follower are lower and they decline significantly faster than the $R \& D$ investments of the Stackelberg leader. Each enterprise supplies the lowest value of the final product when a research joint venture is formed, which also results in the highest market price. Under price leadership, a larger extent of knowledge spillovers in the industry leads to the reduction of $R \& D$ expenditures by both enterprises. The highest price of the final product is set when a research joint venture is formed. In a cartelized industry, the lowest values of $R \& D$ expenditures occur when there are no knowledge spillovers between enterprises, or when they form a research joint venture at the $R \& D$ stage. The highest values of $R \& D$ investments are observed for the medium values of knowledge spillovers. Performed analysis allows to conclude that tightening of cooperation in research and development between competitors creates incentives for them to fully cartelize the market.
\end{abstract}

Key words: $R \& D$ cooperation, knowledge spillovers, incentives to cartelize market, quantity leadership, price leadership

JEL classification: L13, L41, O31

\footnotetext{
* Received: 20-05-2017; accepted: 27-11-2018

1 The research was supported by National Science Centre, Poland, grant number UMO-2017/25/B/ HS4/01632.

2 Ph.D., Vice Dean of Graduate Studies, Warsaw School of Economics, Department of Business Economics, Al. Niepodleglosci 162, 02-554 Warsaw, Poland. Scientific affiliation: applied microeconomics, industrial organization. Phone: +4822564 6855. Fax: +48225648633. E-mail: adam.karbowski@sgh.waw.pl (correspondingauthor).

${ }^{3}$ Full Professor, Vice Rector for International Relations, Warsaw School of Economics, Department of Business Economics, Al. Niepodleglosci 162, 02-554 Warsaw, Poland. Scientific affiliation: computational economics, financial economics. Phone: +4822564 6855. Fax: +48 22564 8633.E-mail: jacek.prokop@sgh.waw.pl.
} 


\section{Introduction}

Along with the growing academic interest in R\&D cooperation (see e.g. Spence, 1984; d'Aspremont and Jacquemin, 1988; Kamien et al., 1992), the policy regulations aimed at promoting cooperation in $R \& D$ among firms have been widely introduced (in Europe, the United States, Japan among other countries or regions, see e.g. Cassiman, 2000; Horvath, 2001; Barajas et al., 2012). According to Marinucci (2012) the initial goal of many policy-makers in promoting R\&D cooperation between enterprises was to increase (or at least maintain) international competitiveness of domestic firms and sectors (cf. e.g. the SEMATECH program in the United States aimed at advancing semiconductor manufacturing, ESPRIT program in Europe oriented at information technology development and transfer, or VLSI program in Japan focused on improving semiconductor technologies and circuits). In recent years, public programs addressing $R \& D$ are being however created to enhance the competitiveness of a given economic area (for example, the comprehensive EU Framework Program, for details, please see Marinucci, 2012).

The European Commission has supported R\&D cooperation among enterprises for many years (Geroski, 1993; van Wegberg, 1995; Cassiman, 2000; Georghiou, 2001; Barajas et al., 2012). The European policy-makers claim that interfirm R\&D cooperation allows to promote the exchange of know-how and technologies, to facilitate technical and economic progress, and to rationalise the manufacture and use of products that benefit consumers among others (Commission Regulation (EC) No 2659/2000). The significant role of cooperation in R\&D is clearly expressed in the EU2020 strategy which underlines the importance of properly linking different areas of European knowledge systems, i.e. innovation, research and higher education (Maassen and Stensaker, 2011). In Europe it is widely recognized that the relations and synergies between innovation, research and higher education are the main drivers of the knowledge economy (Veugelers and Mrak, 2009).

The European Union has set up special institutions aimed at promoting cooperation in European R\&D. The flagship example may be here the European Institute of Innovation and Technology (EIT) which provides an important bridging function in Horizon 2020 from excellence-driven higher education, research and technology to innovation (eit.europa.eu). The EIT strives to fully integrate three sides of the knowledge triangle which encompasses innovation, research and higher education (for details, please see Soriano and Mulatero, 2010; Maassen and Stensaker, 2011).

Several governments have also stimulated the formation of $R \& D$ cooperation between enterprises by providing more lenient antitrust rules (Marinucci, 2012). For instance, the American legal acts (cf. National Cooperative Research Act) state that all enterprises willing to cooperate in research and development that file in a national register will be evaluated by antitrust authorities under the rule of reason 
rather than the per se rule (Marinucci, 2012). Therefore, it seems quite natural to ask whether such policy direction is justified or not.

In recent years, the important questions about the potential harmful side-effects of R\&D cooperation between enterprises are posed (see e.g. Martin, 2006; Miyagiwa, 2009; Belleflamme and Peitz, 2010; Prokop and Karbowski, 2013). The burning question arises whether the facilitation of cooperation among firms at the R\&D stage may lead to the formation of a cartel on the final product market, what eventually can exert negative effects on the consumer surplus (Prokop and Wiśnicki, 2015). Can R\&D cooperation between enterprises be a steppingstone to collusion on the final product market? It remains the central question to the following research.

The purpose of this research is to examine how R\&D cooperation between firms influences the incentives to create a cartel in the final product market. We consider a case when the R\&D expenditures reduce the unit costs of production and at the same time generate positive externalities for competitors (a case of process innovations generating knowledge spillovers will be here considered). The R\&D investments of one enterprise create positive externalities for the other firms in the industry by helping them decrease their costs of production (similar approach can be found e.g. in d'Aspremont and Jacquemin, 1988, Kamien et al., 1992, see also Geroski, 1995 for a wider discussion on knowledge spillovers in the industry). We hypothesize that under such market setup, the tightening of cooperation in research and development between competitors creates incentives for them to fully cartelize the industry.

The remainder of this article proceeds as follows. In the next section, the review of relevant literature is present. In section 3, the model of a noncooperative duopoly (there is no cartel neither in R\&D, nor in the final product market), and industrywide cartel is developed. The model considers three cases. The first case focuses on the industry characterized by the Stackelberg leadership in the product market. The second case looks at the price leadership form of competition. The third case concentrates on the conduct (as well as performance) of companies that formed a cartel in the final product market and at the same time coordinated their R\&D expenditures. Section 4 contains numerical data which constitute the solution to the model. Based on the comparison of the above-mentioned three cases, the incentives for the enterprises to invest in technology enhancements (process innovations) and to create a cartel in the product market are discussed in section 5. Conclusions (drawn in section 6) close the paper.

\section{Literature review}

According to Amir and colleagues (2001) R\&D cooperation between firms is a particularly active area of research in the field of industrial economics. Pioneered 
by Larry E. Ruff (1969), the theoretical literature on R\&D cooperation between enterprises had a forceful take-off after a 15-year dormant time, following the research by Spence (1984), Katz (1986), d'Aspremont and Jacquemin (1988), Kamien and colleagues (1992), Salant and Shaffer (1998; 1999), Amir and colleagues $(2000 ; 2001)$, Kamien and Zang (2000), Petrakis and Poyago-Theotoky (2002), Atallah (2005), Cellini and Lambertini (2009), Bourreau and Dogan (2010), Bandyopadhyay and Mukherjee (2014), Czarnitzki and colleagues (2015), and Bourreau and colleagues (2016), among others. According to Amir and colleagues (2001) this strand of industrial economics literature may be viewed as a straightforward extension of the heated debate, initiated by Joseph A. Schumpeter (1942), on the relationship between market structure and enterprise innovation. $R \& D$ cooperation between enterprises constitutes a specific organizational/market structure that encompasses cooperation of firms in research and development and at the same time fierce competition (rivalry) between companies in the final product market (Kamien et al., 1992).

However, in recent years some researchers suggest that interfirm R\&D cooperation can in fact serve a collusive function (Belleflamme and Peitz, 2010; Sovinsky and Helland, 2012). As a result, enterprises cooperating in research and development may collude on the product market to the detriment of social welfare (Prokop and Wiśnicki, 2015). To our best knowledge, such possibility was first considered by Prokop and Karbowski (2013), but in the context of fairly similar enterprises ("a symmetric case").

It is worth noting here that cartels are not necessarily formed among enterprises with fairly similar characteristics what at least to some extent substantiates the need of a consideration of an asymmetric case, in which a leader-follower relationship can be detected. The examples of historical market collusions show that the cartel members could significantly differ in size and/or market share. For instance, the district heating pipe cartel detected by the European Commission in 1995 consisted of ten enterprises with substantially different market shares (for details, please cf. Commission Decision Case IV/35.691/E-4).

A leader-follower relationship considered in the context of possible cartel formation on the final product market has been partly investigated and discussed in the economic literature (for a succinct review, please see Tirole, 1988). Shaffer (1995) provides a formal reasoning for the Stackelberg sequence (quantity leadership) in the context of cartel creation. Prokop (2014) compares the effects of the quantity leadership competition of two business firms on their R\&D investments with the situation of a fully cartelized industry, under quadratic cost functions. A leaderfollower relationship in the context of cartel formation has been also analyzed within the price leadership models of competition discussed by d'Aspremont and colleagues (1983) and Donsimoni and colleagues (1986). However, none of these papers devoted to price leadership includes the role of process innovations and 
knowledge spillovers in the context of cartel creation. The following paper aims to address the research gap delineated above.

Similarly to the previous literature on the topic (cf. e.g. d'Aspremont and Jacquemin, 1988; De Bondt and Veugelers, 1991), the following analysis is based on a twostage game with two enterprises as players. At the first game stage, the enterprises simultaneously decide upon the values of R\&D expenditures, and at the second stage of the game, they compete in the final product market. Unlike the previous literature in the field, it has been assumed that in the case of no cartel agreement in the final product market, the enterprises compete according to the leadership model (both quantity leadership and price leadership are here considered and compared) what reflects the "asymmetric case".

\section{Model}

Let us first focus on an industry comprised of two enterprises, labelled 1 and 2 . Each enterprise $i(i=1,2)$ produces $q_{i}$ units of a homogeneous good. The inverse market demand for the good is given as a linear function in the following form:

$$
p=a-Q,
$$

where $p$ stands for the market price, $Q=q_{1}+q_{2}$ constitutes the volume of total production in the industry, while $a(a>0)$ is a given parameter. Let us further consider the production costs of enterprise $i$ in the form of the following quadratic function:

$$
C_{i}\left(q_{i}, x_{i}, x_{j}\right)=\frac{q_{i}{ }^{2}}{c+x_{i}+\beta x_{j}},
$$

where $c(c<a)$ constitutes a parameter of an initial efficiency of a given enterprise, $x_{i}$ stands for R\&D expenditures made by the enterprise $i$, and $x_{j}$ denotes the R\&D investments made by i's rival. Parameter $\beta(0 \leq \beta \leq 1)$ determines the size of knowledge spillovers (Geroski, 1995) in the industry, i.e. the benefits for a given enterprise obtained as a result of research and development undertaken by the enterprise's rival. Higher value of $\beta$ means that the R\&D investments made by one company exert a larger impact on manufacturing cost reduction of the rival. In contrast to the seminal papers in the field, i.e. d'Aspremont and Jacquemin (1988) and Kamien and colleagues (1992), the total costs of production are here considered as quadratic what implies the existence of the increasing marginal costs of production and makes our model more externally valid.

Following d'Aspremont and Jacquemin (1988) approach, it is further assumed that each company $i$ incurs the costs of research and development according to the following quadratic function: 


$$
\gamma \frac{x_{i}^{2}}{2}
$$

where $\gamma(\gamma>0)$ constitutes a given parameter. Such specification of the R\&D costs allows to model diminishing returns to R\&D spendings that occur in business practice. The entry barriers to the industry are viewed as too high for new enterprises to enter.

There are two decision stages in our model. At the first stage, both companies simultaneously select their research expenditure levels, $x_{i}$. These decisions directly affect the values of manufacturing costs of each enterprise according to formula 2. At the second stage, the enterprises compete in the final product market and behave according to one of the leadership forms (quantity or price leadership) discussed below.

Let us first consider the case when the industry competition is characterized by the quantity leadership in the final product market. Assume that company 1 plays the role of the Stackelberg leader, and company 2 plays the role of the Stackelberg follower. Company 1 is then the first to set its level of production, $q_{1}$, and company 2 , knowing the supply level determined by the leader, decides upon its own level of production, $q_{2}$.

Let us next find the subgame perfect equilibrium of this two-stage game. In order to do that we first consider the profit of the Stackelberg follower at the second stage of the game (for a given value of research expenditures made by both companies, $x_{1}$ and $x_{2}$ ):

$$
\pi_{2}=(a-Q) q_{2}-\frac{q_{2}^{2}}{c+x_{2}+\beta x_{1}}-\gamma \frac{x_{2}^{2}}{2} .
$$

Given the production level of the leader company, $q_{1}$, the follower maximizes its own profit by setting the output level at:

$$
q_{2}=\frac{\left(a-q_{1}\right)\left(c+\beta x_{1}+x_{2}\right)}{2\left(1+c+\beta x_{1}+x_{2}\right)},
$$

which is computed by solving the first order condition $\left(\frac{\partial \pi_{2}}{\partial q_{2}}=0\right.$ ) with respect to $q_{2}$. Please note that formula 5 constitutes the reaction function of the follower firm in our duopoly market. Considering further the reaction function of the follower, the leader maximizes its own profit for given values of R\&D expenditures made by both enterprises, $x_{1}$ and $x_{2}$ :

$$
\pi_{1}=(a-Q) q_{1}-\frac{q_{1}^{2}}{c+x_{1}+\beta x_{2}}-\gamma \frac{x_{1}^{2}}{2}
$$


Please observe that the profit function given by formula 6 can be rearranged as a function of one variable only, i.e., $q_{1}$ :

$$
\pi_{1}=\frac{q_{1}\left(a-q_{1}\right)\left(2+c+\beta x_{1}+x_{2}\right)}{2\left(1+c+\beta x_{1}+x_{2}\right)}-\frac{q_{1}^{2}}{c+x_{1}+\beta x_{2}}-\frac{1}{2} \gamma x_{1}^{2} .
$$

Next, the first order condition for profit optimization, $\frac{d \pi_{1}}{d q_{1}}=0$, generates the optimal supply level for the leader company:

$$
q_{1}=\frac{a\left(2+c+\beta x_{1}+x_{2}\right)\left(c+x_{1}+\beta x_{2}\right)}{2\left(\left(2+c+\beta x_{1}+x_{2}\right)\left(c+x_{1}+\beta x_{2}\right)+2\left(1+c+\beta x_{1}+x_{2}\right)\right)}
$$

By substituting (8) into (5), we obtain next the optimal production of the follower:

$$
q_{2}=\frac{a\left(c+\beta x_{1}+x_{2}\right)\left(\left(2+c+\beta x_{1}+x_{2}\right)\left(c+x_{1}+\beta x_{2}\right)+4\left(1+c+\beta x_{1}+x_{2}\right)\right)}{4\left(1+c+\beta x_{1}+x_{2}\right)\left(\left(2+c+\beta x_{1}+x_{2}\right)\left(c+x_{1}+\beta x_{2}\right)+2\left(1+c+\beta x_{1}+x_{2}\right)\right)}
$$

It is worth stressing here that the outputs $q_{1}$ and $q_{2}$ given by (8) and (9), constitute the so called Nash-Stackelberg equilibrium of the game for given levels of research investments made by both companies, $x_{1}$ and $x_{2}$.

Next, after substituting (8) and (9) into (4) and (7), we obtain the profits of each enterprise, $\pi_{1}$ and $\pi_{2}$, as the functions of $R \& D$ investments made by both leader and follower, $x_{1}$ and $x_{2}$. Now, we can easily find the profit-maximizing values of R\&D spendings of both companies. In the first stage of the game, when companies simultaneously decide upon their research spendings, $x_{1}$ and $x_{2}$, the Nash equilibrium strategies are obtained as a solution to the following set of equations in two unknowns, $x_{1}$ and $x_{2}$ :

$$
\frac{\partial \pi_{i}}{\partial x_{i}}=0, i=1,2
$$

Let us denote the solution of the above system of equations by $x_{1}^{*}$ and $x_{2}^{*}$. Substituting the calculated values of R\&D investments made by companies into (8) and (9), we obtain next the equilibrium levels of output for the leader company and the follower company, $q_{1}^{*}$ and $q_{2}^{*}$. From formula 1 , we receive the equilibrium price, $p^{*}$. Now, we can also find the equilibrium levels of profits, $\pi_{1}^{*}$ and $\pi_{2}^{*}$. Using numerical analysis, we consider the case of $a=100, c=1$, and $y=150$. The received equilibrium results for various levels of parameter $\beta$ (various levels of knowledge spillovers) are summarized in table 1 in section 4 devoted to data analysis.

Let us next focus on the case when the competition of enterprises in the final product market is characterized by price leadership. Please assume that company 1 plays here the role of the price leader, and company 2, is the price follower (pricetaker). Firm 1 is then the one to set the price level, $p$, and firm 2, takes that price as given, and further decides upon its level of output, $q_{2}$, at that price. Again, we look 
for a subgame perfect equilibrium of the above duopoly game. In order to find this equilibrium, we first consider the profit of the follower company at the second stage of the game, for a given value of research expenditures made by both players, $x_{1}$ and $x_{2}$ :

$$
\pi_{2}=p q_{2}-\frac{q_{2}^{2}}{c+x_{2}+\beta x_{1}}-\gamma \frac{x_{2}^{2}}{2}
$$

Taking the price, $p$, set by the leader firm, as given, the follower maximizes its own profit by setting the production level at:

$$
q_{2}(p)=\frac{1}{2} p\left(c+x_{2}+\beta x_{1}\right)
$$

which can be computed by solving the first order condition, $\frac{\partial \pi_{2}}{\partial q_{2}}=0$, with respect to $q_{2}$.

Given the reaction function of company 2 to the price level, the residual demand for the firm 1 is:

$$
q_{1}=a-\mathrm{p}-q_{2}(\mathrm{p})=\mathrm{a}-\frac{1}{2} p\left(2+c+x_{2}+\beta x_{1}\right) .
$$

The firm 1's profit function can be expressed as:

$$
\pi_{1}=p q_{1}-\frac{q_{1}^{2}}{c+x_{1}+\beta x_{2}}-\gamma \frac{x_{1}^{2}}{2}
$$

Now, taking into account the residual demand function from formula 13, the leader's profit can be presented in the following form:

$$
\pi_{1}(p)=p\left[a-\frac{1}{2} p\left(2+c+x_{2}+\beta x_{1}\right)\right]-\frac{\left[a-\frac{1}{2} p\left(2+c+x_{2}+\beta x_{1}\right)\right]^{2}}{c+x_{2}+\beta x_{1}}-\gamma \frac{x_{1}^{2}}{2} .
$$

The first order condition for the profit maximization of the leader enterprise would be: $\frac{\partial \pi_{i}\left(x_{1}, x_{2}\right)}{\partial x_{i}}=0, \quad i=1,2$.

For given R\&D expenditures made by both players, $x_{1}$ and $x_{2}$, the profit-maximizing price is received as the solution to the above first order condition with respect to $p$. Let us denote the resulting solution as $p\left(x_{1}, x_{2}\right)$. By substituting $p=p\left(x_{1}, x_{2}\right)$ into (13) and (12), we can easily obtain the levels of each firm's supply as functions of $x_{1}$ and $x_{2}$. Please denote them as $q_{1}\left(x_{1}, x_{2}\right)$ and $q_{2}\left(x_{1}, x_{2}\right)$, respectively. Next, by substituting $p=p\left(x_{1}, x_{2}\right)$ and $q_{1}=q_{1}\left(x_{1}, x_{2}\right)$ as well as $q_{2}=q_{2}\left(x_{1}, x_{2}\right)$ into (15) and (11), we receive the optimal levels of profits for given values of $x_{1}$ and $x_{2}$. Let us denote them as $\pi_{1}\left(x_{1}, x_{2}\right)$ and $\pi_{2}\left(x_{1}, x_{2}\right)$. 
Now, please look back at the first stage of the game, when companies simultaneously decide upon their R\&D investments, $x_{1}$ and $x_{2}$. The Nash equilibrium strategies of both firms can be obtained as a solution to the following set of equations in two unknowns, $x_{1}$ and $x_{2}$ :

$$
\frac{\partial \pi_{i}\left(x_{1}, x_{2}\right)}{\partial x_{i}}=0, \quad i=1,2
$$

Please denote the solution of the above set of equations as $\hat{x}_{1}$ and $\hat{x}_{2}$. Now, by substituting the computed values of R\&D investments into the expressions $q_{1}\left(x_{1}, x_{2}\right)$, $q_{2}\left(x_{1}, x_{2}\right)$ and $p=p\left(x_{1}, x_{2}\right)$, we obtain the equilibrium levels of output for the leader company and the follower firm, and also the equilibrium price. Please denote them by $\hat{q}_{1}, \hat{q}_{2}$, and $\hat{p}$, respectively. Using formulas 15 and 11 , we can next calculate the equilibrium levels of profits of our duopolists, denoted by $\hat{\pi}_{1}$ and $\hat{\pi}_{2}$. The equilibrium results for various levels of parameter $\beta$ are shown in table 2 in section 4 devoted to data analysis.

Next we are going to consider the case, in which both firms have colluded in research and development, as well as in the final product market. As in the previous case, we proceed here by turning to backward induction. In the second game stage, the enterprises select their final production levels, $q_{1}$ and $q_{2}$, for given values of R\&D expenditures, $x_{1}$ and $x_{2}$ :

$$
\pi=(a-Q) Q-q_{1}{ }^{2} /\left(c+x_{1}+\beta x_{2}\right)-q_{2}^{2} /\left(c+x_{2}+\beta x_{1}\right)-\gamma \frac{x_{1}^{2}}{2}-\gamma \frac{x_{2}^{2}}{2} .
$$

Note that at the symmetric equilibrium, when $x_{1}=x_{2}=x$, the profit-maximizing supply level for each enterprise, $q=q_{1}=q_{2}$, can be received by solving the following optimality condition with respect to $q$ :

$$
\frac{\partial \pi}{\partial q}=0
$$

By solving expression 18, we get:

$$
q=q_{1}=q_{2}=\frac{a(c+(1+\beta) x)}{2+4 c+4(1+\beta) x} .
$$

Next, we can substitute formula 19 into the inverse market demand function given by formula 1, and, as a result, we get the equilibrium price for the final product as a function of $x$ :

$$
p=\frac{a(1+c+(1+\beta) x)}{1+2 c+2(1+\beta) x} .
$$


Observe that in the first stage of the game, when each enterprise selects the R\&D expenditures, $x$, the enterprises' joint profit can be expressed as:

$$
\pi=\frac{a^{2}}{2} \frac{c+(1+\beta) x}{1+2 c+2(1+\beta) x}-\gamma x^{2} .
$$

Since in our model the cartel members share the joint profit equally, each of them earns $\pi_{1}=\pi_{2}=\frac{\pi}{2}$.

The next step in our analysis is to compute the levels of R\&D expenditures that optimize cartel profits. Therefore, we solve the following first order condition with respect to $x$ :

$$
\frac{\partial \pi}{\partial x}=0 .
$$

Please accept that the received value of $R \& D$ expenditures made by each enterprise in the cartelized industry is here denoted by $\tilde{x}$. Next, after substituting $\tilde{x}$ for $x$ into formulas 19 and 20, we can easily find the optimal supply level of each company, $\tilde{q}$, and the equilibrium market price, $\tilde{p}$, respectively. On the basis of (21), we may next compute the joint profit of cartel firms, $\tilde{\pi}$. We can further find the individual profit of enterprise $i$ as $\tilde{\pi}=\tilde{\pi}_{i} / 2$. Using numerical analysis, we consider the same set of values of parameters, i.e. $a=100, c=1$, and $\gamma=150$. The received equilibrium results for various values of parameter $\beta$ are summarized in table 3 in section 4 devoted to data analysis.

\section{Empirical data and analysis}

As indicated above, in this section we are going to present numerical data which constitute solutions to all three cases considered in our model.

Based on table 1 regarding Stackelberg competition, we may observe the impact of parameter $\beta$, i.e. the size of knowledge spillovers in the industry, on the equilibrium behaviour of enterprises. Please observe that the R\&D expenditures of companies decline with the increasing scale of knowledge spillovers (growing $\beta$ ) in the industry. The relative research spendings of the follower firm are lower, and they decline significantly faster than the R\&D investments of the leader company. For $\beta=0$, the ratio of investments is approximately 1.2 , and for $\beta=$ 1 it becomes as much as 3.5. Please bear in mind that, following Kamien and colleagues (1992), the research joint venture (RJV) is characterized by $\beta=1$, since companies in RJV completely share their knowledge and fully disclose their information. 
Table 1: Stackelberg equilibrium for $a=100, c=1, \gamma=150$, and $\beta \in[0,1]$

\begin{tabular}{|c|c|c|c|c|c|c|c|}
\hline$\beta$ & $x_{1}^{*}$ & $x_{2}^{*}$ & $q_{1}^{*}$ & $q_{2}^{*}$ & $p^{*}$ & $\pi_{1}^{*}$ & $\pi_{2}^{*}$ \\
\hline 0.0 & 1.208440 & 1.04283 & 29.7334 & 23.5870 & 46.6796 & 878.101 & 747.128 \\
\hline 0.1 & 1.125290 & 0.94592 & 29.7804 & 23.6302 & 46.5894 & 892.967 & 762.544 \\
\hline 0.2 & 1.050060 & 0.855727 & 29.7805 & 23.6574 & 46.5620 & 904.666 & 775.686 \\
\hline 0.3 & 0.981520 & 0.77065 & 29.7350 & 23.6704 & 46.5946 & 913.650 & 787.058 \\
\hline 0.4 & 0.918817 & 0.689332 & 29.6436 & 23.6702 & 46.6862 & 920.208 & 797.038 \\
\hline 0.5 & 0.861418 & 0.610528 & 29.5045 & 23.6578 & 46.8377 & 924.496 & 805.929 \\
\hline 0.6 & 0.809137 & 0.532985 & 29.3142 & 23.6340 & 47.0518 & 926.542 & 813.989 \\
\hline 0.7 & 0.762224 & 0.455270 & 29.0670 & 23.6001 & 47.3329 & 926.231 & 821.469 \\
\hline 0.8 & 0.721606 & 0.375487 & 28.7540 & 23.5587 & 47.6872 & 923.246 & 828.658 \\
\hline 0.9 & 0.689457 & 0.290665 & 28.3608 & 23.5154 & 48.1237 & 916.921 & 835.976 \\
\hline 1.0 & 0.670688 & 0.195237 & 27.8614 & 23.4837 & 48.6549 & 905.838 & 844.183 \\
\hline
\end{tabular}

Source: Authors' calculations

For the values of parameter $\beta$ higher than 0.3 , an increase in the size of knowledge spillovers leads to a lower supply of the final product by both enterprises. Each company supplies the lowest amount of the final product when the research joint venture is formed $(\beta=1)$, which results in the highest market price. Thus, a research joint venture will also lead to the lowest consumer surplus.

Note also that the profit of each company is affected by the parameter $\beta$ value in different ways. On the one hand, the profit of the follower company increases monotonically with a wider extent of knowledge spillovers, and achieves its maximum when the companies form a research joint venture. On the other hand, the leader company profit initially grows when the parameter $\beta$ increases, but it starts declining when this parameter value exceeds 0.6. Thus, it seems that under the Stackelberg competition in the final product market, a research joint venture is beneficial to the follower firm, but not much attractive to the leader, who prefers only a medium level of knowledge spillovers.

Let us now turn to the price leadership competition. Based on table 2, it is now possible to describe the impact of knowledge spillovers on the equilibrium conduct and performance of enterprises when the competition in the final product market can be captured by the price-leadership model. First, please observe that a larger extent of knowledge spillovers (increasing $\beta$ ) leads to the reduction of R\&D expenditures by both companies. Second, the price leader invests more in $\mathrm{R} \& \mathrm{D}$ than the follower for $\beta \leq 0.7$, but for the higher levels of knowledge spillovers, the follower's investment spendings become larger than those made by the leader. 
Table 2: Price-leadership equilibrium for $a=100, c=1, \gamma=150$, and $\beta \in[0,1]$

\begin{tabular}{|c|c|c|c|c|c|c|c|}
\hline$\beta$ & $\hat{x}_{1}$ & $\hat{x}_{2}$ & $\hat{q}_{1}$ & $\hat{q}_{2}$ & $\hat{p}$ & $\hat{\pi}_{1}$ & $\hat{\pi}_{2}$ \\
\hline 0.0 & 1.086440 & 0.660528 & 26.6352 & 33.2805 & 40.0843 & 639.105 & 634.291 \\
\hline 0.1 & 0.941921 & 0.579159 & 26.0632 & 33.6810 & 40.2558 & 642.980 & 652.771 \\
\hline 0.2 & 0.810830 & 0.506542 & 25.5190 & 33.8776 & 40.6034 & 646.278 & 668.528 \\
\hline 0.3 & 0.690058 & 0.441240 & 24.9884 & 33.8897 & 41.1219 & 649.226 & 682.203 \\
\hline 0.4 & 0.577397 & 0382520 & 24.4605 & 33.7297 & 41.8099 & 651.919 & 694,142 \\
\hline 0.5 & 0.471199 & 0.330252 & 23.9281 & 33.4050 & 42.6669 & 654.383 & 704.464 \\
\hline 0.6 & 0.370063 & 0.287930 & 23.3877 & 32.9208 & 43.6914 & 656.623 & 713.090 \\
\hline 0.7 & 0.272404 & 0.247890 & 22.8409 & 32.2805 & 44.8786 & 658.690 & 719.743 \\
\hline 0.8 & 0.175575 & 0.221946 & 22.2970 & 31.4843 & 46.2187 & 660.815 & 723.887 \\
\hline 0.9 & 0.073599 & 0.213405 & 21.7806 & 30.5195 & 47.6999 & 663.708 & 724.473 \\
\hline 1.0 & 0.000000 & 0.208378 & 21.4818 & 29.5725 & 48.9458 & 669.552 & 720.467 \\
\hline
\end{tabular}

Source: Authors' calculations

The quantity of the final product offered by the price leader is lower than the supply of the follower, and it declines with the growing level of the knowledge spillovers. Please observe that the quantity of the final product offered by the price follower is a non-monotonic function of the size of knowledge spillovers, i.e., this output increases when parameter $\beta$ is below 0.3 , and declines when $\beta$ is above that level. Each firm's output reaches the lowest levels when the research joint venture is formed, i.e., $\beta=1$. The equilibrium market price is an increasing function of the knowledge spillovers. The highest price of the final product is observed in the case of research joint venture.

The profit of the price leader is an increasing function of knowledge spillovers. The profit of the price follower is also growing with larger $\beta$, but it suddenly starts declining when $\beta \geq 0.9$. Thus, when the competition in the final product market is characterized by price leadership, a research joint venture benefits the leader company, but is less attractive to the follower enterprise. According to table 2, the price follower prefers the knowledge spillovers to be at the level of $\beta=0.9$. Finally, it should also be stressed that the profit of the price leader is greater than the profit of the follower only when there are no knowledge spillovers $(\beta=0)$. For $\beta \geq 0.1$, the follower's profit is larger than the profit of the price leader. Next, we move on to analyze the case of interfirm cooperation within a cartel.

Finally, let us now turn to the equilibrium in a cartelized industry. Using table 3, we can analyze the impact of knowledge spillovers on the equilibrium conduct of our companies. For a start, it is worth stressing that in a fully cartelized industry the value of the R\&D investments of companies changes non-monotonically. The lowest values of $R \& D$ expenditures occur when there are no knowledge spillovers, 
or when the enterprises create a research joint venture $(\beta=1)$. The highest levels of R\&D spendings are in turn expected for the medium levels of knowledge spillovers $(\beta=0.8)$ in the industry.

Table 3: Equilibrium of a cartelized industry for $a=100, c=1, \gamma=150$, and $\beta \in[0,1]$

\begin{tabular}{|c|c|c|c|c|}
\hline$\beta$ & $\tilde{x}$ & $\tilde{q}_{i}$ & $\tilde{p}$ & $\tilde{\pi}_{i}$ \\
\hline 0.0 & 0.792684 & 19.5479 & 60.9042 & 930.268 \\
\hline 0.1 & 0.805241 & 19.7606 & 60.4788 & 939.399 \\
\hline 0.2 & 0.814591 & 19.9546 & 60.0908 & 947.964 \\
\hline 0.3 & 0.821450 & 20.1356 & 59.7356 & 956.001 \\
\hline 0.4 & 0.826356 & 20.2953 & 59.4095 & 963.548 \\
\hline 0.5 & 0.829717 & 20.4456 & 59.1089 & 970.646 \\
\hline 0.6 & 0.831846 & 20.5845 & 58.8309 & 977.329 \\
\hline 0.7 & 0.832988 & 20.7134 & 58.5732 & 983.631 \\
\hline 0.8 & 0.833333 & 20.8333 & 58.3333 & 989.583 \\
\hline 0.9 & 0.833033 & 20.9452 & 58.1096 & 995.214 \\
\hline 1.0 & 0.832210 & 21.0498 & 57.9004 & 1000.550 \\
\hline
\end{tabular}

Source: Authors' calculations

Moreover, it seems interesting that in the equilibrium discussed, a larger size of knowledge spillovers makes each company manufacture a higher value of the final output. It certainly leads to a price reduction, but, we should underline here, the prices are still significantly higher than in the non-collusive (competitive) case. The profits earned by each cartel enterprise are monotonically rising together with a growing size of knowledge spillovers.

\section{Results and discussion}

In this section we are going to discuss the results received in the previous section of the paper. In particular, we are going to compare the decisions of companies to enhance the production technology, as well as assess the incentives of enterprises to cartelize the market.

First, let us focus on the decisions of enterprises to undertake the R\&D investments. It is worth stressing that for any level of knowledge spillovers in the industry, the Stackelberg leader spends more on research and development than any firm in the market characterized by the price leadership rivalry. Observe further that in the case of relatively low knowledge spillovers in the industry $(\beta \leq 0.5)$, the Stackelberg leader invests more in research and development than a cartel enterprise. The 
Stackelberg follower invests more in $\mathrm{R} \& \mathrm{D}$ than the price leader for $\beta \geq 0.1$, and that investment is larger than the R\&D spendings of the price follower for $\beta<$ 1. The quantity follower spends more on research and development than a cartel enterprise, however only for $\beta \leq 0.2$.

Now, let us turn to the case of relatively large knowledge spillovers in the industry $(\beta \geq 0.6)$. Note that the process innovation investments made by each enterprise operating in a cartel are higher than the $R \& D$ expenditures made by a firm competing in an industry characterized by the leadership behavior. When a research joint venture is formed, the enterprises participating in a cartel undertake higher $\mathrm{R} \& \mathrm{D}$ investments than the non-colluding companies. It is worth noting here that a similar result has been obtained by d'Aspremont and Jacquemin (1988) in the case of linear production cost functions and the Cournot-type competition in the final product market.

Next, please focus on the price level of the final product. Observe that despite the more efficient production process, the cartel companies offer their final product at a significantly higher price to consumers than the non-colluding enterprises. Further, the simulations show that, for any size of knowledge spillovers in the industry, the lowest market prices of the final product are expected when the industry is characterized by price leadership competition. Therefore, from the viewpoint of the consumers, the price leadership rivalry is here a better type of competition than the quantity leadership.

Finally, let us also consider the firm performance in each of the cases analyzed in previous sections. Independently of the level of knowledge spillovers in the industry, the profits of enterprises in the market characterized by price leadership are lower than the profits obtained by the firms behaving according to the Stackelberg model of duopoly. Thus, the non-colluding firms would prefer here the quantity leadership to the price leadership. The best performance is achieved however under the collusive behavior. No matter the extent of knowledge spillovers in the industry, the profit of a cartel member is higher than the profit of any firm in the non-cartelized industry characterized by the quantity leadership, or price leadership. What is more, the enterprises attain the highest profits when they create a cartel both at the $R \& D$ and production stage, and at the same time form a research joint venture to fully benefit from the mutual knowledge exchange. We may therefore expect that the tightening of cooperation in research and development can create sufficient incentives for the enterprises to cartelize the market. This original result seems to shed some unfavorable light on the R\&D cooperation itself, which is widely believed to promote enterprise innovation and increase social welfare (cf. e.g. d'Aspremont and Jacquemin, 1988; Kamien et al., 1992; Kaiser, 2002; Becker and Dietz, 2004). 


\section{Conclusions}

On the basis of formal analyses presented in the previous sections, we can conclude that the best performance of enterprises (in terms of profits generated) is achieved under the collusive behavior. Independently of the size of knowledge spillovers in the industry, the profit of a firm participating in the cartel is higher than the profit of any company in the non-cartelized market characterized by any form of the leadership behavior. Moreover, the firms earn the highest profits when they coordinate both their R\&D efforts and production decisions as cartel members, and at the same time operate in a research joint venture to maximize the knowledge exchange. This result supports our working hypothesis that the tightening of cooperation in research and development between market rivals creates incentives for the enterprises to cartelize the industry. But, if really R\&D cooperation between market competitors strengthens firms' incentives to behave cooperatively also in the final product market (and this is a claim suggested in this paper), the industrial policy oriented at promoting $\mathrm{R} \& \mathrm{D}$ cooperation (which is nowadays quite common worldwide) could be, at least to some extent, counterproductive (it may in fact work in favor of collusion in the final product market and hence reduction rather than increase of the social welfare). Please bear in mind that the last prediction is supported by the empirical evidence (cf. literature review section). Our paper is theoretical in nature, and all our claims are based on formal reasoning and simulations. Certainly, it constitutes a limitation of the above study, but at the same time it delineates the future research which should empirically test the theoretical predictions produced in this paper.

\section{References}

Amir, R., Evstigneev, I., Wooders, J. (2000) "Noncooperative versus cooperative R\&D with endogenous spillover rates", Games and Economic Behavior, Vol. 42, Issue 2, pp. 183-207, doi: 10.1016/S0899-8256(02)00541-9.

Amir, R., Nannerup, N., Stepanova, A., Eguiazarova, E. (2001) “Monopoly versus R\&D-integrated duopoly", CORE Discussion Paper 2001/51.

d'Aspremont, C., Jacquemin, A., Gabszewicz, J. J., Weymark, J. A. (1983) "On th Stability of Collusive Price Leadership", Canadian Journal of Economics, Vol. 16, No. 1, pp. 17-25.

d'Aspremont, C., Jacquemin, A. (1988) "Cooperative and Noncooperative R\&D in Duopoly with Spillovers", American Economic Review, Vol. 78, No. 5, pp. 1133-37.

Atallah, G. (2005) "R\&D cooperation with asymmetric spillovers", Canadian Journal of Economics, Vol. 38, No. 3, pp. 919-936. 
Bandyopadhyay, S., Mukherjee, A. (2014) "R\&D Cooperation with Entry", The Manchester School, Vol. 82, Issue 1, pp. 52-70, doi: 10.1111/j.1467-9957. 2012.02336.x.

Barajas, A., Huergo, E., Moreno, L. (2012) "Measuring the economic impact of research joint ventures supported by the EU Framework Programme", The Journal of Technology Transfer, Vol. 37, Issue 6, pp. 917-942, doi: 10.1007/ s10961-011-9222-y.

Becker, W., Dietz, J. (2004) "R\&D cooperation and innovation activities of firms evidence for the German manufacturing industry", Research Policy, Vol. 33, Issue 2, pp. 209-223, doi: 10.1016/j.respol.2003.07.003.

Belleflamme, P., Peitz, M. (2010) Industrial Organization. Markets and Strategies, Cambridge: Cambridge University Press.

Bourreau, M., Dogan, P. (2010) "Cooperation in product development and process R\&D between competitors", International Journal of Industrial Organization, Vol. 28, No. 2, pp. 176-190, doi: 10.1016/j.ijindorg.2009.07.010.

Bourreau, M., Dogan, P., Manant, P. (2016) "Size of RJVs with partial cooperation in product development", International Journal of Industrial Organization, Vol. 46, May 2016, pp. 77-106, doi: 10.1016/j.ijindorg.2016.04.004.

Cassiman, B. (2000) "Research joint ventures and optimal R\&D policy with asymmetric Information", International Journal of Industrial Organization, Vol. 18, Issue 2, pp. 283-314, doi: 10.1016/S0167-7187(98)00013-7.

Cellini, R., Lambertini, L. (2009) "Dynamic R\&D with Spillovers: Competition vs Cooperation", Journal of Economic Dynamics and Control, Vol. 33, Issue 3, pp. 568-582, doi: 10.1016/j.jedc.2008.08.006.

Czarnitzki, D., Hussinger, K., Schneider, C. (2015) "R\&D Collaboration with Uncertain Intellectual Property Rights", Review of Industrial Organization, Vol. 46, Issue 2, pp. 183-204, doi: 10.1007/s11151-015-9449-0.

De Bondt, R., Veugelers, R. (1991) "Strategic Investment with Spillovers", European Journal of Political Economy, Vol. 7, Issue 3, pp. 345-366, doi: 10.1016/0176-2680(91)90018-X.

Donsimoni, M. P., Economides, N. S., Polemarchakis, H. M. (1986) "Stable cartels", International Economic Review, Vol. 27, No. 2, pp. 317-327.

eit.europa.eu.

Georghiou, L. (2001) "Evolving frameworks for European collaboration in research and technology", Research Policy, Vol. 30, Issue 6, pp. 891-903, doi: 10.1016/ S0048-7333(00)00163-3.

Geroski, P. (1993) "Antitrust policy towards co-operative R\&D ventures", Oxford Review of Economic Policy, Vol. 9, No. 2, pp. 58-71.

Geroski, P. (1995) "Do spillovers undermine the incentive to innovate?". In Dowrick, S. ed., Economic approaches to innovation, Aldershot: Edward Elgar. 
Horvath, R. (2001) Cooperation in Research and Development, Barcelona: Universitat Autonoma de Barcelona.

Kaiser, U. (2002) "An empirical test of models explaining research expenditures and research cooperation: evidence for the German service sector", International Journal of Industrial Organization, Vol. 20, Issue 6, pp. 747-774, doi: 10.1016/S0167-7187(01)00074-1.

Kamien, M. I., Muller, E., Zang, I. (1992) "Research Joint Ventures and R\&D Cartels", American Economic Review, Vol. 82, No. 5, pp. 1293-1306.

Kamien, M. I., Zang, I. (2000) "Meet me halfway: research joint ventures and absorptive capacity", International Journal of Industrial Organization, Vol. 18, Issue 7, pp. 995-1012, doi: 10.1016/S0167-7187(00)00054-0.

Katz, M. (1986) "An Analysis of Cooperative Research and Development", RAND Journal of Economics, Vol. 17, No. 4, pp. 527-543.

Marinucci, M. (2012) A primer on $R \& D$ cooperation among firms, The Bank of Italy Occasional Paper Number 130.

Martin, S. (2006) "Competition policy, collusion, and tacit collusion", International Journal of Industrial Organization, Vol. 24, Issue 6, pp. 159-176, doi: 10.1016/ j.ijindorg.2006.04.007.

Maassen, P., Stensaker, B. (2011) "The knowledge triangle, European higher education policy logics and policy implications", High Educ, Vol. 61, Issue 6, pp. 757-769, doi: 10.1007/s10734-010-9360-4.

Miyagiwa, K. (2009) "Collusion and Research Joint Ventures", The Journal of Industrial Economics, Vol. 57, Issue 4, pp. 768-784, doi: 10.1111/j.1467-6451. 2009.00399.x.

Petrakis, E., Poyago-Theotoky, J. (2002) "R\&D Subsidies versus R\&D Cooperation in a Duopoly with Spillovers and Pollution", Australian Economic Papers, Vol. 41, Issue 1, pp. 37-52, doi: 10.1111/1467-8454.00148.

Prokop, J., Karbowski, A. (2013) "R\&D Cooperation and Industry Cartelization", The Economics Discussion Paper Series 2013-41, The Kiel Institute for the World Economy.

Prokop, J. (2014) "Research Joint Ventures and Cartelization of Industries", Procedia Economics and Finance, Vol. 14, pp. 507-514, doi: 10.1016/S22125671(14)00742-4.

Prokop, J., Wiśnicki, B. (2015) "R\&D Activities in Oligopoly and Social Welfare", International Journal of Management and Economics, Vol. 46, Issue 1, pp. 134-146, doi: 10.1515/ijme-2015-0025.

Ruff, L. (1969) "Research and technological progress in a Cournot economy", Journal of Economic Theory, Vol. 1, Issue 4, pp. 397-415.

Salant, S., Shaffer, G. (1998) "Optimal asymmetric strategies in research joint ventures", International Journal of Industrial Organization, Vol. 16, Issue 2, pp. 195-208, doi: 10.1016/S0167-7187(96)01046-6. 
Salant, S., Shaffer, G. (1999) "Unequal treatment of identical agents in Cournot equilibrium", American Economic Review, Vol. 89, No. 3, pp. 585-604.

Schumpeter, J. A. (1942) Capitalism, Socialism and Democracy, New York: Harper and Bros.

Shaffer, S. (1995) "Stable Cartels with a Cournot Fringe", Southern Economic Journal, Vol. 61, No. 3, pp. 744-754, doi: 10.2307/1060994, www.jstor.org/ stable/1060994.

Soriano, F., Mulatero, F. (2010) "Knowledge Policy in the EU: From the Lisbon Strategy to Europe 2020", J Knowl Econ, Vol. 1, Issue 4, pp. 289-302, doi: 10.1007/s13132-010-0020-9.

Sovinsky, M., Helland, E. (2012) "Do Research Joint Ventures Serve a Collusion Function?", Warwick Economic Research Papers Number 1030.

Spence, M. (1984) "Cost Reduction, Competition, and Industry Performance", Econometrica, Vol. 52, No. 1, pp. 101-121, doi: 10.2307/1911463, www.jstor. org/stable/1911463.

Tirole, J. (1988) The Theory of Industrial Organization, Cambridge: MIT Press.

Veugelers, R., Mrak, M. (2009) The Knowledge Economy and Catching up Member States of the EU, Brussels: European Commission.

van Wegberg, M. (1995) "Can R\&D alliances facilitate the formation of a cartel? The example of the European IT industry", Research Memoranda 004 Maastricht Research School of Economics of Technology and Organization. 


\title{
Aktivnosti istraživanja i razvoja poduzeća, vodstvo tržišta proizvoda i koluzija
}

\author{
Adam Karbowski ${ }^{1}$, Jacek Prokop ${ }^{2}$
}

\begin{abstract}
Sažetak
Svrha ovog istraživanja je usporediti posljedice, prvo, kvantitativnog vodstva $i$, drugo, cjenovnog vodstva u konkurenciji duopola na njihova ulaganja $u$ istraživanje i razvoj u situaciji industrije s obilježjima kartela. Pokazalo se da primjenom pristupa teorije igre i numeričke analize pod kvantitativnim vodstvom, ulaganja u istraživanje i razvoj poduzeća padaju s rastućim prelijevanjem znanja u industriji. Primjenom Stackelbergova modela duopola, utvrđujemo da je razlika između poduzeća koja slijedi i vodećeg poduzeća u tome da su relativni izdaci za istraživanje $i$ razvoj sljedbenika značajno niži $i$ brže se smanjuju od ulaganja vodećeg poduzeća u istraživanje i razvoj. Svako poduzeće određuje najnižu vrijednost konačnog proizvoda kada se formira zajedničko ulaganje, što također rezultira najvećom tržišnom cijenom. Pod cjenovnim vodstvom, veće prelijevanje znanja u industriji dovodi do smanjenja izdataka za istraživanje i razvoj za oba poduzeća. Najviša cijena konačnog proizvoda utvrđuje se kada se osnuje zajedničko ulaganje za istraživanje. $U$ industriji udruženoj u kartele dolazi do najnižih vrijednosti izdataka za istraživanje i razvoj kada nema prelijevanja znanja između poduzeća ili kada osnuju zajedničko ulaganje u fazi istraživanja i razvoja. Najveće vrijednosti ulaganja $u$ istraživanje $i$ razvoj promatraju se za srednje vrijednosti prelijevanja znanja. Iz provedene analize može se zaključiti da se pojačanjem suradnje u istraživanju i razvoju između konkurenata stvaraju poticaji da u potpunosti kreiraju tržište s obilježjima kartela.
\end{abstract}

Ključne riječi: suradnja u istraživanju i razvoju, prelijevanje znanja, poticaji za kartelizaciju tržišta, kvantitativno vodstvo, cjenovno vodstvo

JEL klasifikacija: L13, L41, O31

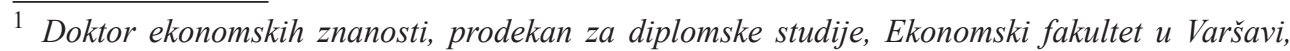
Odsjek za poslovnu ekonomiju, Al. Niepodleglosci 162, 02-554 Varšava, Poljska. Znanstveni interes: primijenjena mikroekonomija, industrijska organizacija. Tel: +4822564 6855. Fax: +4822564 8633.E-mail: adam.karbowski@sgh.waw.pl (osoba za kontakt).

2 Redoviti profesor, prorektor za međunarodne odnose, Ekonomski fakultet u Varšavi, Odsjek za poslovnu ekonomiju, Al. Niepodleglosci 162, 02-554 Varšava, Poljska. Znanstveni interes: računalna ekonomija, financijska ekonomija. Tel.: +4822564 6855. Fax: +48225648633. E-mail: jacek.prokop@sgh.waw.pl. 